\title{
The Impact of Rising Energy Prices on Household Energy Consumption and Expenditure Patterns: The Persian Gulf Crisis as a Case Example
}




\section{Argonne National Laboratory}

Argonne National Laboratory, with facilities in the states of Illinois and Idaho, is owned by the United States government, and operated by the University of Chicago under the provisions of a contract with the Department of Energy.

This technical memo is a product of Argonne's Energy Systems (ES)

Division. For information on the division's scientific and engineering activities, contact:

Director, Energy Systems Division

Argonne National Laboratory

Argonne, Illinois 60439-4815

Telephone (708) 252-3724

Presented in this technical memo are preliminary results of ongoing work or work that is more limited in scope and depth than that described in formal reports issued by the ES Division.

\section{Disclaimer}

This report was prepared as an account of work sponsored by an agency of the United States Govemment. Neither the United States Govemment nor any agency thereof, nor any of their employees, makes any warranty, express or implied, or assumes any legal liability or responsibility for the accuracy, completeness, or usefulness of any information, apparatus, product, or process disclosed, or represents that its use would not infringe privately owned rights. Reference herein to any specific commercial product, process, or service by trade name, trademark, manufacturer, or otherwise, does not necessarily constitute or imply its er, torsement, recommendation, or favoring by the United States Goven ment or any agency thereof. The views and opinions of authors expressed herein do not necessarily state or reflect those of the United States Govemment or any agency thereof.

Reproduced directly from the best available copy.

Available to DOE and DOE contractors from the Office of Scientific and Technical Information, P.O. Box 62, Oak Ridge, TN 37831; prices available from

(615) 576-8401.

Available to the public from the National Technical Information Service, U.S. Department of Commerce, 5285 Port Royal Road, Springfield, VA 22161. 


\section{The Impact of Rising Energy Prices on Household Energy Consumption and Expenditure Patterns: The Persian Gulf Crisis as a Case Example}

by L.J. Henderson, “ D.A. Poyer, and A.P.S. Teotia

Energy Systems Division,

Argonne National Laboratory, 9700 South Cass Avenue, Argonne, Illinois 60439

September 1992

Work sponsored by United States Department of Energy, Office of Minority Economic Impact

*Henderson is affiliated with the University of Baltimore. 


\section{Contents}

Acknowledgments.............................................................. v

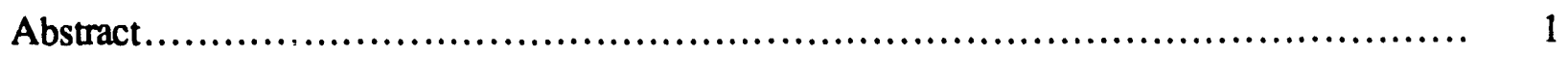

1 Introduction.................................................................. 1

2 Modeling Household Energy Consumption and Expenditure $\ldots \ldots \ldots \ldots \ldots \ldots \ldots \ldots \ldots \ldots . \ldots$

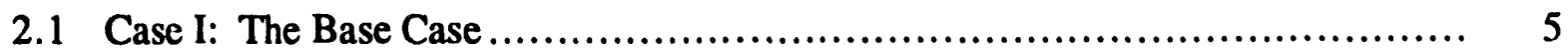

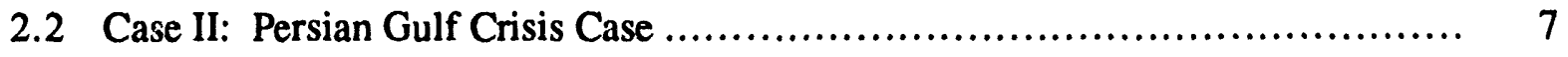

3 Household Economic Effects Associated with Alternative Cases...................... 9

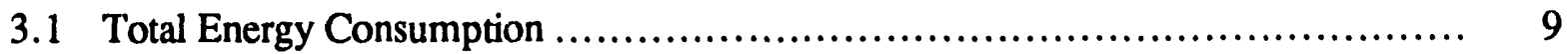

3.2 Total Energy Expenditures ............................................... 13

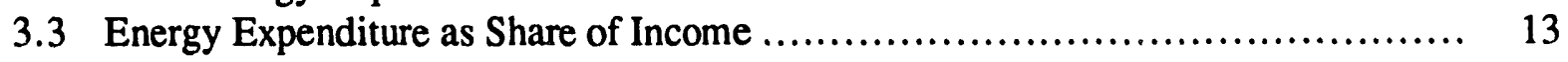

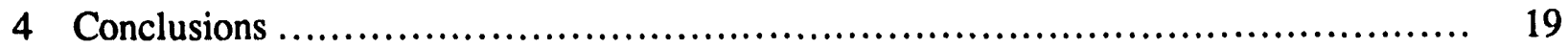

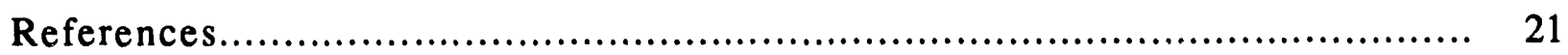

Figures

1 Multistage Budget Model................................................... 4

2 Average Annual Price of Imported Crude Oil, in Nominal Dollars per Barrel, under Alternative Cases................................................................

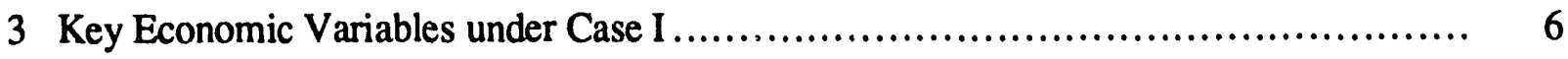

4 Energy Consumption of Majority Households under Alternative Cases ............... 10

5 Energy Consumption of Black Households under Alternative Cases ................ 10

6 Energy Consumption of Hispanic Households under Alternative Cases................... 11

7 Energy Consumption of Poor Households under Alternative Cases .................. 11

8 Energy Consumption of Nonpoor Households under Alternative Cases ................ 12 


\section{Figures (Cont.)}

9 Energy Consumption of Majority, Black, and Hispanic Households under Alternative Cases.

10 Energy Consumption of Poor and Nonpoor Households under Alternative Cases.

11 Energy Expenditures of Majority Households under Alternative Cases.

12 Energy Expenditures of Black Households under Alternative Cases

13 Energy Expenditures of Hispanic Households under Alternative Cases

14 Energy Expenditures of Poor Households under Alternative Cases.

15 Energy Expenditures of Nonpoor Households under Alternative Cases

16 Energy Expenditure as Share of Income for Majority, Black, and Hispanic Households under Alternative Cases

17 Energy Expenditure as Share of Income for Poor and Nonpoor Households under Alternative Cases

\section{Tables}

1 Annual Rates of Change in Key Macroeconomic and Energy Variables under Case I: 1989-1999

2 Annual Rates of Change in Key Macroeconomic and Energy Variables under Case II: $1989-1999$

3 Total Energy Consumption.................................................. 9

4 Total Energy Expenditures .................................................... 14

5 Total Energy Expenditure as Share of Income................................. 17 


\section{Acknowledgments}

The support of the U.S. Department of Energy (DOE) research program manager, Georgia Johnson, is gratefully acknowledged. Reviews and comments were provided by Larry Johnson, Director, Center for Transportation Research at Argonne National Laboratory (ANL). The authors extend their thanks to ANL staff members Leslie Crosser for word processing assistance; Linda Haley, Mary Jo Koelbl, and Laurie Culbert for graphics support; and Kevin Brown for editorial advice and assistance. 


\title{
The Impact of Rising Energy Prices on Household Energy Consumption and Expenditure Patterns: The Persian Gulf Crisis as a Case Example
}

\author{
by
}

\author{
L.J. Henderson, D.A. Poyer, and A.P.S. Teotia
}

\begin{abstract}
The Iraqi invasion of Kuwait and the subsequent war between Iraq and an international alliance led by the United States triggered immediate increases in world oil prices. Increases in world petroleum prices and in U.S. petroleum imports resulted in higher petroleum prices for U.S. customers. In this report, the effects of the Persian Gulf War and its aftermath are used to demonstrate the potential impacts of petroleum price changes on majority, black, and Hispanic households, as well as on poor and nonpoor households. The analysis is done by using the Minority Energy Assessment Model developed by Argonne National Laboratory for the U.S. Department of Energy (DOE). The differential impacts of these price increases and fluctuations on poor and minority households raise significant issues for a variety of government agencies, including DOE. Although the Persian Gulf crisis is now over and world oil prices have returned to their pre-war levels, the differential impacts of rising energy prices on poor and minority households as a result of any future crisis in the world oil market remains a significant long-term issue.
\end{abstract}

\section{Introduction}

Like the sharp increases in foreign crude oil prices brought about by the Arab oil embargo (1973-74) and the Iran crisis (1979-80), the Iraqi invasion of Kuwait on August 2, 1990, triggered immediate increases in world petroleum prices. Increases in petroleum prices and i: U.S. petroleum imports resulted in higher petroleum prices for U.S. residential, commercial, and industrial consumers. The effect was an immediate price shock that reverberated throughout the U.S. economy.

The differential impact of these price increases and fluctuations on poor and minority households raised immediate, significant, and potentially long-term research, policy, and management issues for a variety of federal, state, and local government agencies, including the U.S. Department of Energy (DOE). Three of these issues are listed below: 
1. The measurement of variations in the impact of changes in petroleum prices on poor, nonpoor, minority, and majority households.

2. How to use existing policy resources and policy innovation to mitigate regressive impacts of petroleum price increases on lower-income households.

3. How to pursue such policy mitigation through government agencies severely circumscribed by tax and expenditure limitations.

Few models attempt to assess household energy consumption and energy expenditure under (1) various alternative price scenarios and (2) with respect to the inclusion of differential household choices correlated with such variables as race, ethnicity, income, and geographic location.

This report provides a preliminary analysis of the nature and extent of potential impacts of petroleum price changes attributable to the Persian Gulf War and its aftermath on majority, black, Hispanic, poor, and nonpoor households. The analysis is done by using the Minority Energy Assessment Model (MEAM) developed by Argonne National Laboratory (ANL) for DOE. At the time this report was written, the Persian Gulf War had concluded with Iraq's total surrender to all of the resolutions and demands of the United Nations and United States. Operation Desert Storm deployed thousands of U.S. and allied troops, as well as aircraft, naval vessels, and other equipment, to the Persian Gulf. President Bush indicated that the objectives of the war were to deter the Iraqi invasion of Saudi Arabia, force Iraq out of Kuwait, and secure U.S. petroleum interests in the region.

The outcome of these initiatives, particularly the surrender of Iraq, the uncertain future of Iraq's leadership, and the general uncertainty in the region could stimulate short-term fluctuations in petroleum prices, longer-term increases in world petroleum prices, and subsequent impacts on U.S. household energy prices that could significantly alter patterns of household energy consumption, particularly in minority and/or poor households. 


\section{Modeling Household Energy Consumption and Expenditure}

As is discussed in Section 1, MEAM is used for the analysis of household energy consumption and expenditure patterns. MEAM is a multistage budgeting model estimated by means of the SAS (SAS Institute, 1984) three-stage nonlinear estimation procedure developed by Amemiya (1985). The model provides a framework with which to forecast energy consumption and expenditures for various types of households. MEAM is used to analyze the differential impact of changing energy markets on the energy consumption and economic welfare of two groups of households in the United States: (1) majority and minority and (2) poor and nonpoor. The welfare implications of the revealed consumption patterns by households are also forecast. Structural parameters have been estimated by using a longitudinal sample consisting of approximately 5,000 observations from four Residential Energy Consumption Surveys (RECS) conducted by DOE (see DOE, 1982, 1985, 1987, and 1989).

The analysis is done within the context of a well-structured theoretical framework. Standard neoclassical consumer-behavior theory is used, along with a complete demand system of equations derived from a constrained utility-maximization problem. The utility function is similar to the Stone-Geary utility function, which is derived from a modified version of the linear expenditure system (LES)." The analysis is done under the assumption that the demand for energy and non-energy goods is separable, thereby allowing for the construction of a multistage budgeting model. Figure 1 is a conceptual presentation of the model. The explanatory variables in the model include the following:

- Household expenditures,

- Electricity price,

- Nonelectricity energy price, and

- Consumer price index (CPI), excluding energy.

The model consists of the four equations listed below, which provide estimates of total household energy consumption (equation 1), electricity consumption (equation 2), the weighted household energy price (equation 3), and energy expenditures (equation 4).

\footnotetext{
* For a discussion on the general theory underlying the LES model, see Geary, (1940-51), Klein and Rubin (194748), Samuelson (1947-48), and Stone (1954). Muellbauer (1975) and Pollak and Wales (1981) discuss the incorporation of demographic factors into a complete demand system. The development of a dynamic LES model is covered in the work by Phlips (1972 and 1983).
} 


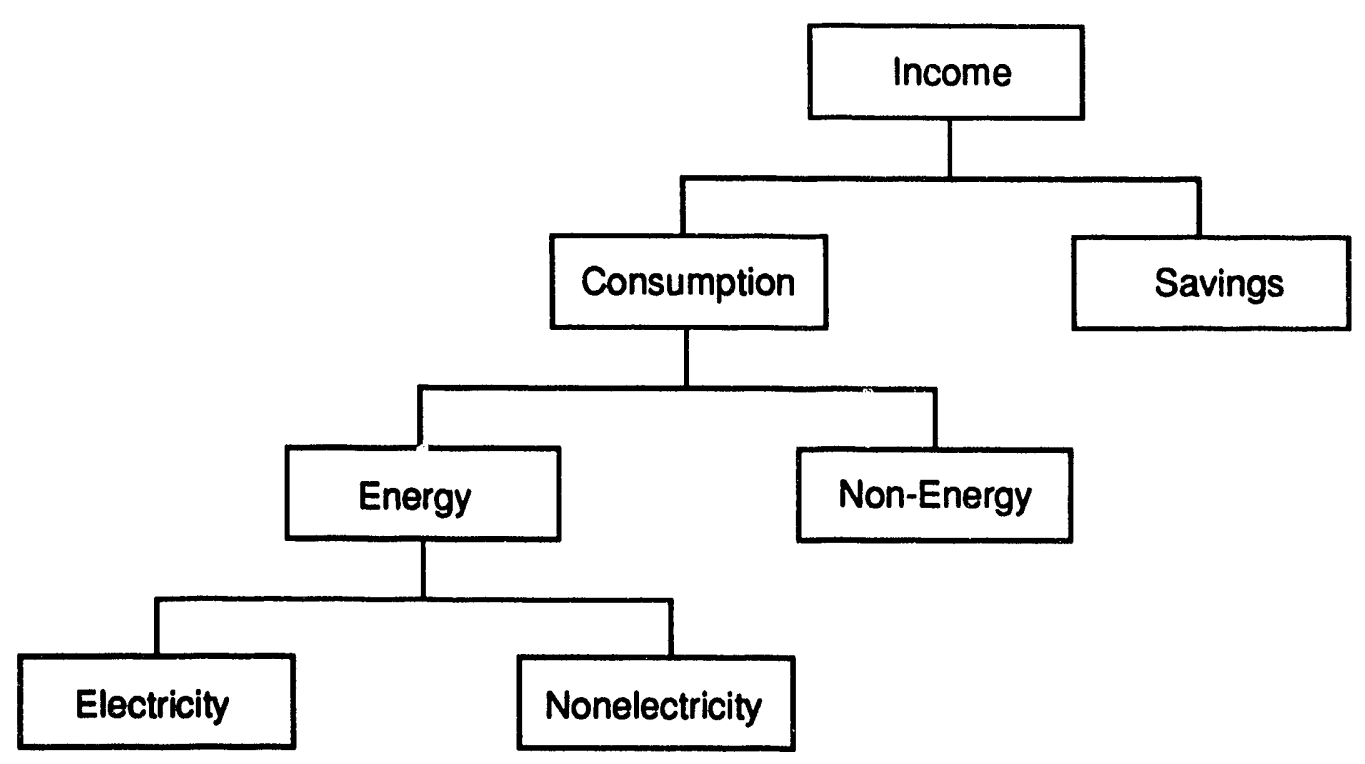

FIGURE 1 Multistage Budget Model

$$
\begin{aligned}
& \mathrm{q}_{\mathrm{et}}=\frac{\left(1-\beta_{\mathrm{e}}\right)\left(\gamma_{\mathrm{e}}+\alpha \theta \mathrm{S}_{\mathrm{t}-1}\right) \psi_{\mathrm{et}}}{\left[1-\psi_{\mathrm{et}} \alpha(1-\theta)\right]}+\frac{\beta_{\mathrm{e}}}{\mathrm{p}_{\mathrm{et}}}\left(\mathrm{m}_{\mathrm{t}}-\mathrm{p}_{\mathrm{ct}} \gamma_{\mathrm{c}}\right) \\
& \mathrm{q}_{\mathrm{elt}}=\left(1-\beta_{\mathrm{el}}\right) \psi_{\mathrm{elt}} \gamma_{\mathrm{el}}+\frac{\beta_{\mathrm{el}}[1-\alpha(1-\theta)]\left\{\mathrm{m}_{\mathrm{et}}-\frac{\mathrm{p}_{\mathrm{nell}}\left(\gamma_{\mathrm{e}}+\alpha \theta \mathrm{S}_{\mathrm{t}}-1-\gamma_{\mathrm{el}}\right)}{[1-\alpha(1-\theta)]}\right\}}{\left\{[1-\alpha(1-\theta)] \mathrm{p}_{\mathrm{elt}}+\alpha(1-\theta) \mathrm{p}_{\mathrm{nelt}}\right)} \\
& \mathrm{p}_{\mathrm{et}} \equiv \frac{\left(\mathrm{p}_{\mathrm{elt}} \mathrm{q}_{\mathrm{elt}}+\mathrm{p}_{\mathrm{nelt}} \mathrm{q}_{\mathrm{nelt}}\right)}{\mathrm{q}_{\mathrm{et}}}
\end{aligned}
$$

and

$$
\mathrm{m}_{\mathrm{et}} \equiv \mathrm{p}_{\mathrm{et}} \mathrm{q}_{\mathrm{et}}
$$

where: $q_{\mathrm{et}}=$ energy consumption $\left(10^{6} \mathrm{Btu} / \mathrm{yr}\right)$,

$\Psi_{\mathrm{et}}=$ energy-demand scale îactor,

$\gamma_{\mathrm{e}}=$ nondiscretionary energy demand $\left(10^{6} \mathrm{Btu} / \mathrm{yr}\right)$,

$\alpha=$ dynamic effect parameter,

$\boldsymbol{\theta}=$ dynarnic adjustment parameter,

$S_{t-1}=$ state variable in period $t-1$, 


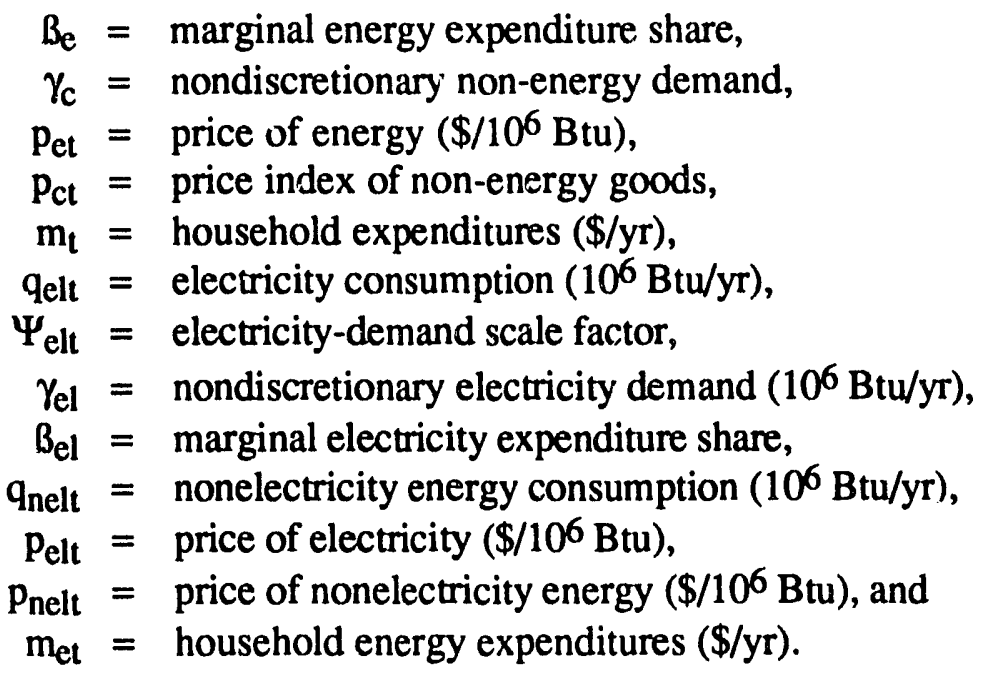

The energy- and electricity-demand scale factors play an extremely important role in our analysis: they are used to introduce the potential effect of exogenous factors (such as housing turnover and interregional population migration) on energy demand. The analysis presented in this report assumes that the energy-demand curve for each of the five population groups falls by $10 \%$, while the electricity-demand curves rise by $10 \%$.

In addition to these exogenous shifts in demand, the effects of two energy-price scenarios - a base case and a Persian Gulf Crisis case - on energy consumption and expenditures are analyzed.

\subsection{Case i: The Base Case}

The base-case energy forecast was based on macroeconomic and energy variable forecasts obtained from Data Resources, Inc. (DRI, 1990a). Figure 2 shows the nominal cost of imported crude oil under this scenario, which was prepared in the spring of 1990 . As the gap between the demand for and supply of world oil narrows during the 1990s, crude oil prices are forecast to rise moderately during the first half of the 1990s and then rise at a double-digit rate during the second half of the $1990 \mathrm{~s}$. As a result, crude oil prices will increase to $\$ 18.50 / \mathrm{barrel}^{*}$ in $1990, \$ 25.40 / \mathrm{bbl}$ in 1995 , and $\$ 41.50 / \mathrm{bbl}$ in 2000 . Figure 3 shows the average annual rate of increase over the last two years of selected key economic variables (used in MEAM) from 1989 to 1999. The rate at which nominal household income is forecast to increase is higher than the rate of inflation (as measured by the CPI), which, in turn, will be higher than the rate at which electricity prices will increase throughout the 1990s. However, the rate at which the price of nonelectricity fuels escalates will exceed the rate at which the following increase: the price of electricity in 1991, the CPI in 1992, and household income in 1993. Some of the Case I variable projections are provided in Table 1. The historical values were also obtained from DRI (1989).

\footnotetext{
${ }^{*}$ Abbreviated in the text as bbl.
} 


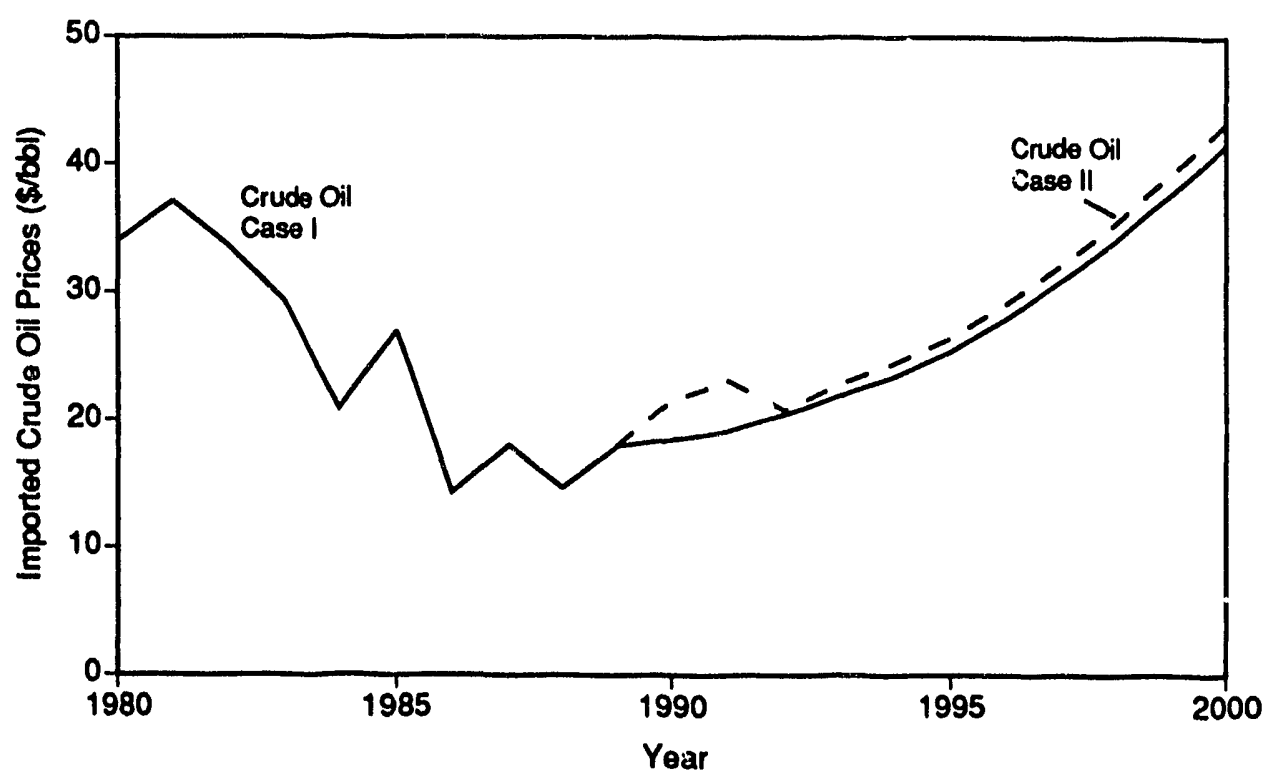

FIGURE 2 Average Annual Price of imported Crude Oil, in Nominal Dollars per Barrel, under Alternative Cases

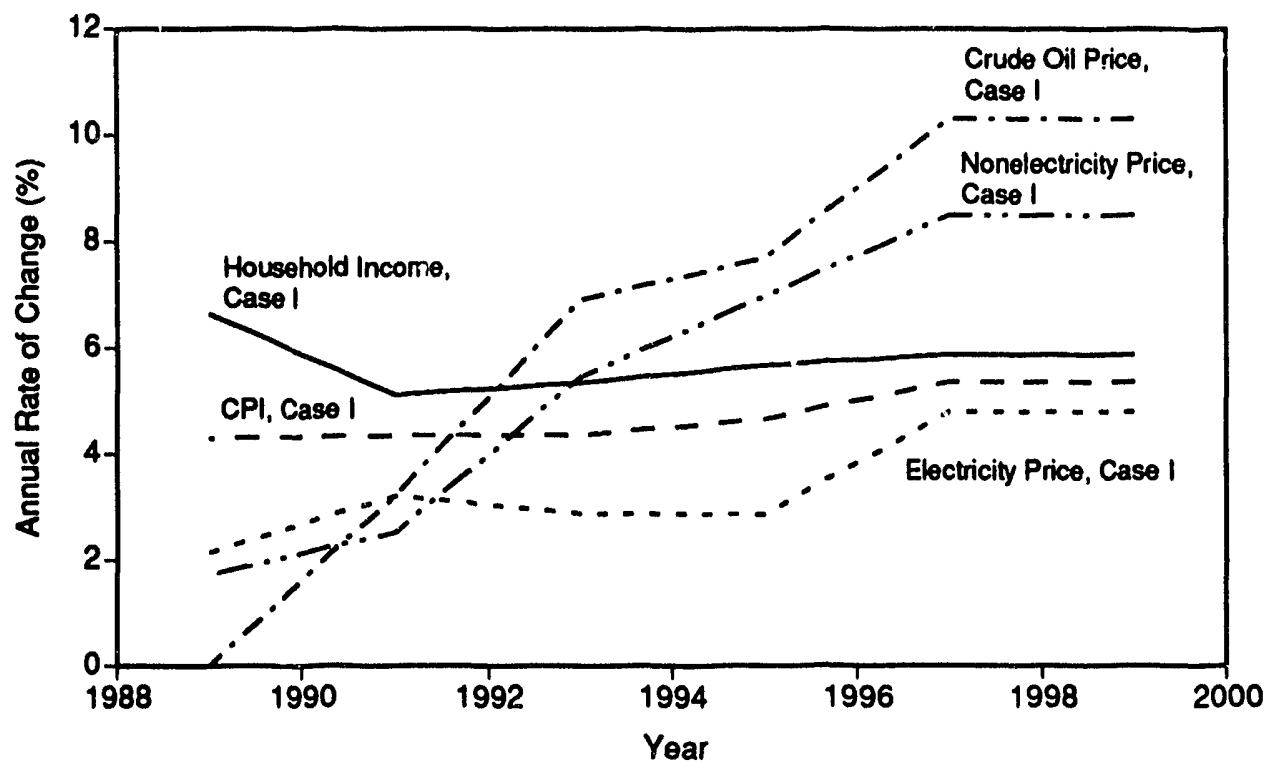

FIGURE 3 Key Economic Variables under Case I (annual rates of change over the preceding two-year periods) 
TABLE 1 Annual Rates of Change in Key Macroeconomic and Energy Variables under Case I: 1989-1999

\begin{tabular}{lll}
\hline & \multicolumn{2}{c}{$\begin{array}{c}\text { Percent Change, } \\
\text { by Period }\end{array}$} \\
\cline { 2 - 3 } \multicolumn{1}{c}{ Variable } & $1989-93$ & $1993-99$ \\
\hline & & \\
\hline & & \\
Household income & 5.22 & 5.81 \\
CPI & 4.33 & 5.16 \\
Electricity price & 3.04 & 4.23 \\
Nonelectricity energy price & 3.97 & 8.06 \\
\hline
\end{tabular}

Sources: DRI 1989 and 1990a.

The forecast time horizon was broken into two periods: 1989-1993 and 1993-1999. Essentially, these periods could be considered intermediate and long-run periods, respectively. The DRI estimates were used to represent the base case prevailing for the period between 1990 and 1999.

\subsection{Case II: Persian Gulf Crisis Case}

Case II is a special case that is based on the DRI macroeconomic scenario "Control 0990" (1990b), released after the Iraqi invasion of Kuwait in August 1990. This scenario incorporates the new DRI crude-oil-price trajectory over the 1990-93 period (Figure 2).

As a result of the events in the Persian Gulf, the world crude-oil market has demonstrated dramatic volatility with respect to oil prices. Prior to the Iraqi invasion on August 2, 1990, crude oil prices in the United States were just over \$20/bbl (DRI, 1990b). Because of various developments during the armed conflict in the Persian Gulf, the price of crude oil surged above $\$ 30 / b b l$ in August 1990 . Prices fell by the end of the month as the Oil Producing and Exporting Countries (OPEC) temporarily suspended production quotas; West Texas Intermediate and OPEC spot prices retreated to $\$ 27 / \mathrm{bbl}$. Because of these conditions, the average price of crude oil is projected to be $\$ 27.90 / \mathrm{bbl}$ in the fourth quarter of 1990 , which corresponds to an average annual price of $\$ 21.50 / \mathrm{bbl}$ in 1990 (Figure 2). Even though - as per the scenario assumption - the embargo of Iraqi and Kuwaiti crude oil is likely to extend into mid-1991, the increased production by other OPEC members is expected to leave total world oil production in 1991 just $1.5 \times 10^{6} \mathrm{bbl} /$ day below pre-invasion forecasts. Consequently, the average price of crude oil is expected to be $\$ 23.17 / \mathrm{bbl}$ in 1991 . Under the assumption that Iraqi and Kuwaiti production will be restored to $80 \%$ of pre-war levels by the end of 1992 and to $100 \%$ of pre-war levels by 1993 , 
the price of crude oil will gradually fall to $\$ 20.80 / \mathrm{bbl}$ in 1992 before slowly firming to the basecase projection of $\$ 23.50$ by late 1993 . The forecast of the four variables given in Table 1 is assumed to be the same under both scenarios (Case I and Case II) for the 1994-1999 period. The variable forecasts for the entire period (1989-99) are provided in Table 2. The values for crude oil prices are subject to large variations that can result from uncertain developments in the Middle East.

TABLE 2 Annual Rates of Change in Key Macroeconomic and Energy Variables under Case II: 1989-1999

\begin{tabular}{lll}
\hline & \multicolumn{2}{c}{$\begin{array}{c}\text { Percent Change, } \\
\text { by Period }\end{array}$} \\
\cline { 2 - 3 } \multicolumn{1}{c}{ Variable } & $1989-93$ & $1993-99$ \\
\hline & & \\
\hline & & \\
Household income & 4.73 & 5.81 \\
CPI & 4.42 & 5.16 \\
Electricity price & 3.15 & 4.23 \\
Nonelectricity energy price & 6.55 & 8.06 \\
\hline
\end{tabular}

Sources: DRI 1990a and 1990b. 


\section{Household Economic Effects Associated with Alternative Cases}

\subsection{Total Energy Consumption}

Table 3 lists the estimated 1989 household energy consumption by majority, black, Hispanic, poor, and nonpoor groups. Among these groups, total energy consumption was highest for blacks (112 × $\left.10^{6} \mathrm{Btu} / \mathrm{household}\right)$ and lowest for Hispanics $\left(88 \times 10^{6} \mathrm{Btu} / \mathrm{household}\right)$.

Figures 4 through 8 show forecasts of household electricity and nonelectricity energy consumption for the above groups under Case I. As presented in Table 1, for all households, the prices of nonelectricity fuel (primarily natural gas and fuel oil) escalate faster than the prices of electricity. Nonelectricity energy consumption declines, while electricity consumption increases (but not enough to offset the decline); these phenomena leave each group's total energy consumption slightly lower (Figures 9 and 10). The conservation in total annual energy consumption from 1989 to 1999 is lowest for poor households (5\%) and highest for nonpoor households (8\%).

Under Case II, the gap between nonelectricity and electricity prices is forecast to be larger than the gap under Case I (Tables 1 and 2). Thus, on a comparative basis for each of the household groups, nonelectricity energy consumption is lower under Case II than under Case I, while electricity use is slightly higher under Case II than under Case I (Figures 4 to 8). Because the decrease in nonelectricity consumption is greater than the increase in electricity consumption, each group's total energy consumption remains slightly lower under Case II than under Case I (Figures 9 and 10). Table 3 provides energy consumption estimates for each of the groups for selected years.

TABLE 3 Total Energy Consumption

\begin{tabular}{|c|c|c|c|c|c|}
\hline \multirow[b]{3}{*}{ Group } & \multicolumn{5}{|c|}{$\begin{array}{l}\text { Total Energy Consumption } \\
\left(10^{6} \text { Btu/household }\right) \text {, by Case }\end{array}$} \\
\hline & \multicolumn{3}{|c|}{ Case I } & \multicolumn{2}{|c|}{ Case II } \\
\hline & 1989 & 1993 & 1999 & 1993 & 1999 \\
\hline Majority & 101.9 & 98.7 & 94.8 & 98.6 & 94.6 \\
\hline Black & 111.7 & 107.7 & 103.8 & 107.6 & 103.8 \\
\hline Hispanic & 88.4 & 85.4 & 82.5 & 85.2 & 82.4 \\
\hline Poor & 91.2 & 88.3 & 86.5 & 88.3 & 86.5 \\
\hline Nonpoor & 104.9 & 101.1 & 96.3 & 100.9 & 96.2 \\
\hline
\end{tabular}




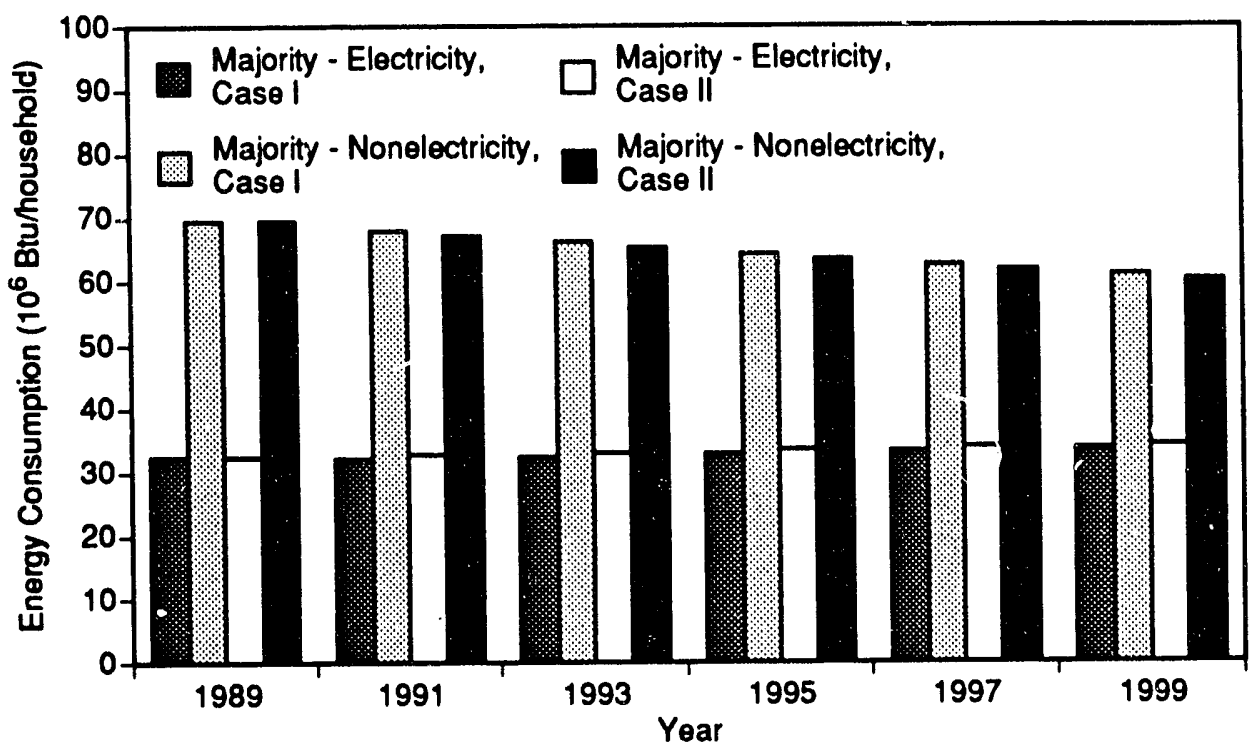

FIGURE 4 Energy Consumption of Majority Households under Alternative Cases

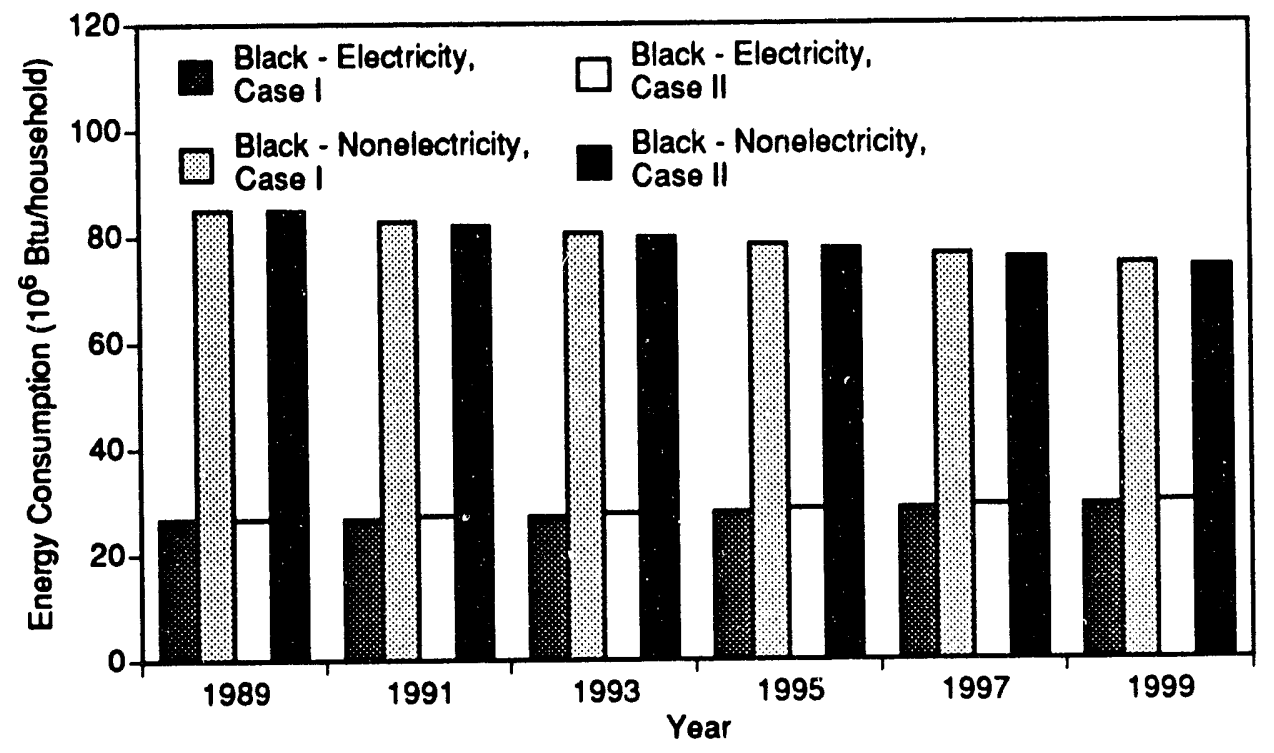

FIGURE 5 Energy Con!sumption of Black Households under Alternative Cases 


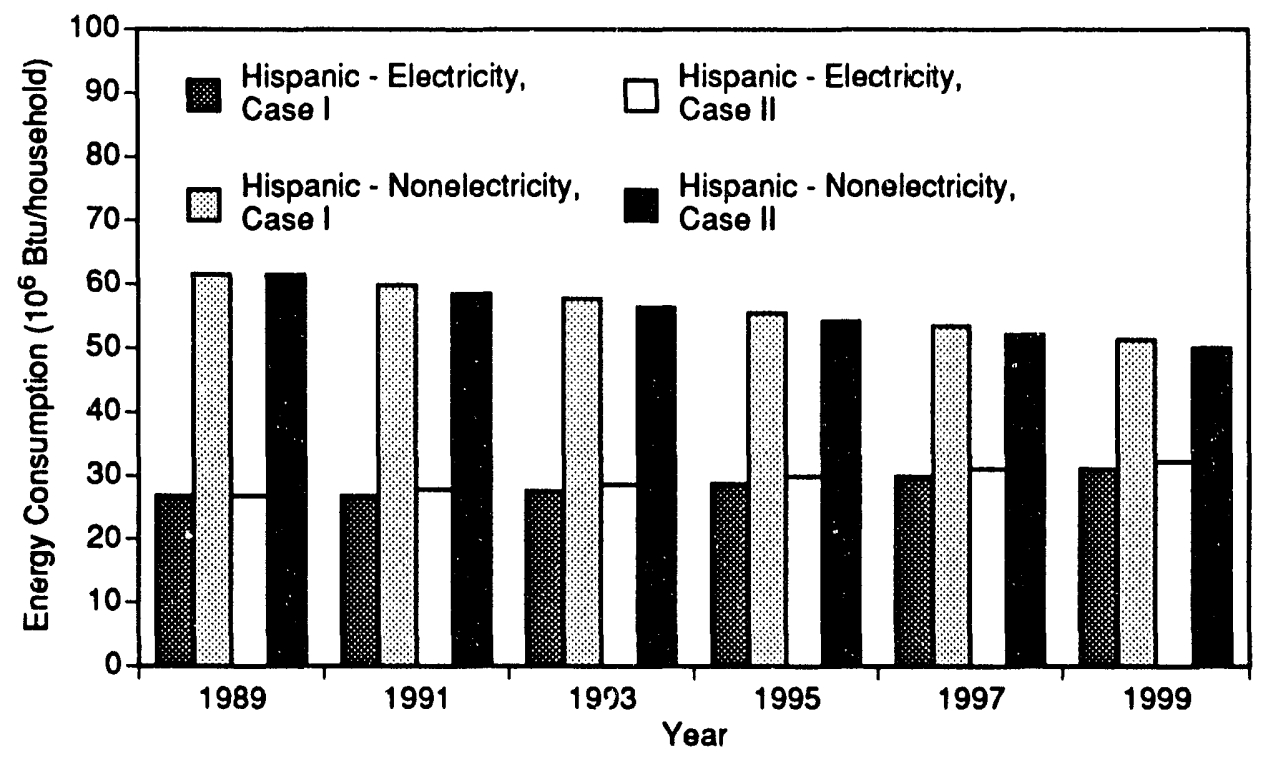

FIGURE 6 Energy Consumption of Hispanic Households under Alternative Cases

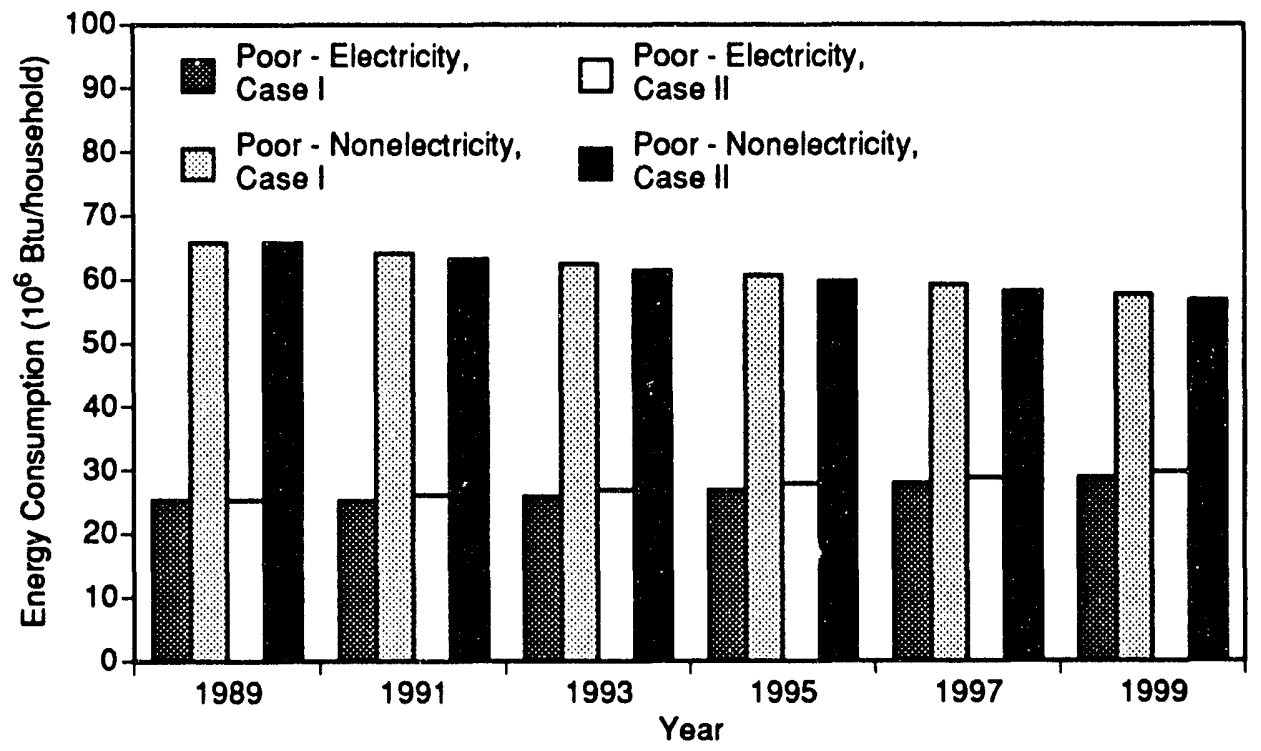

FIGURE 7 Energy Consumption of Poor Households under Alternative Cases 


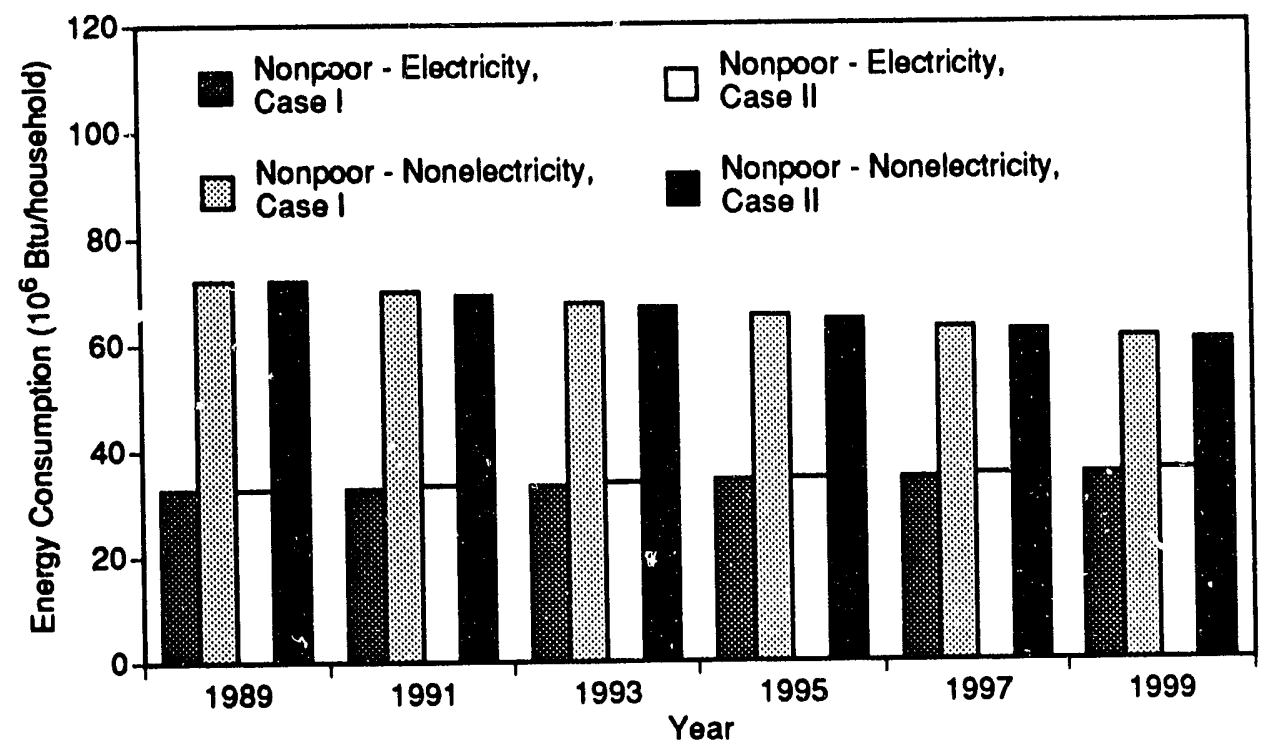

FIGURE 8 Energy Consumption of Nonpoor Households under Alternative Cases

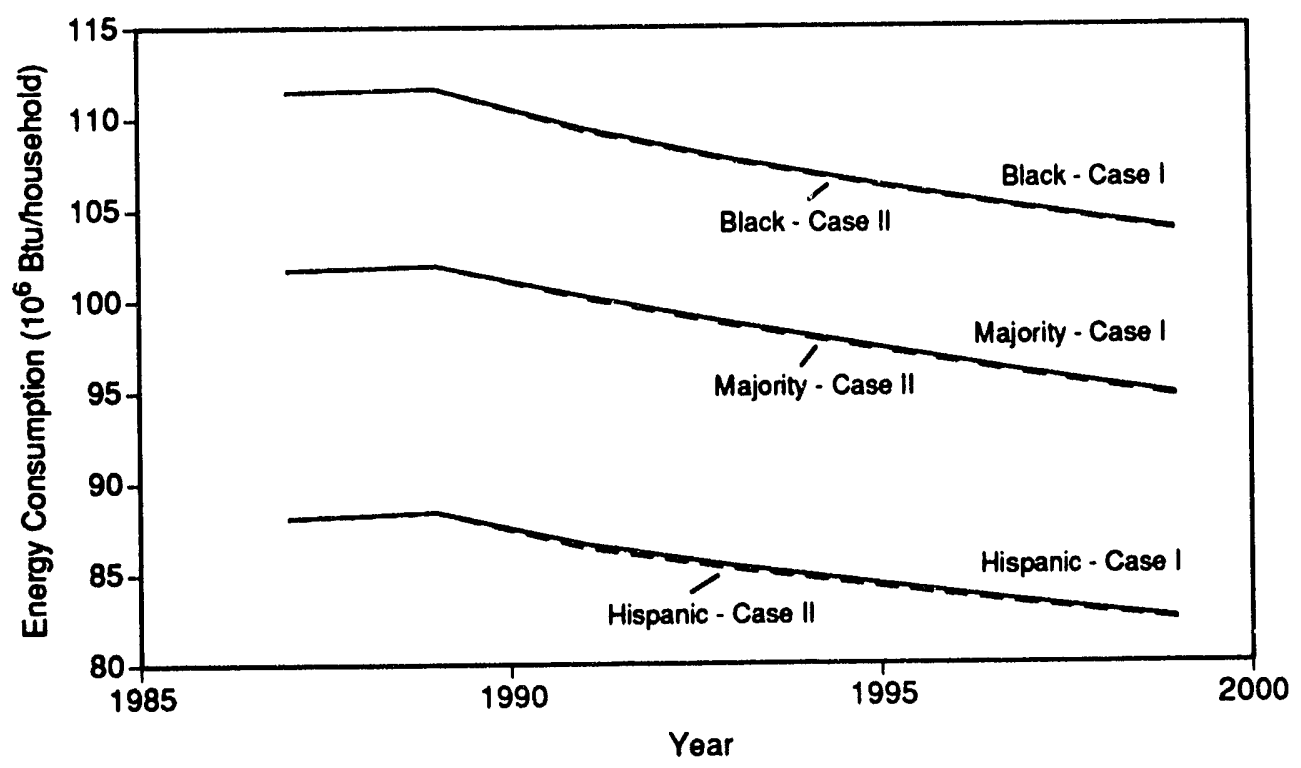

FIGURE 9 Energy Consumption of Majority, Black, and Hispanic Households under Alternative Cases 


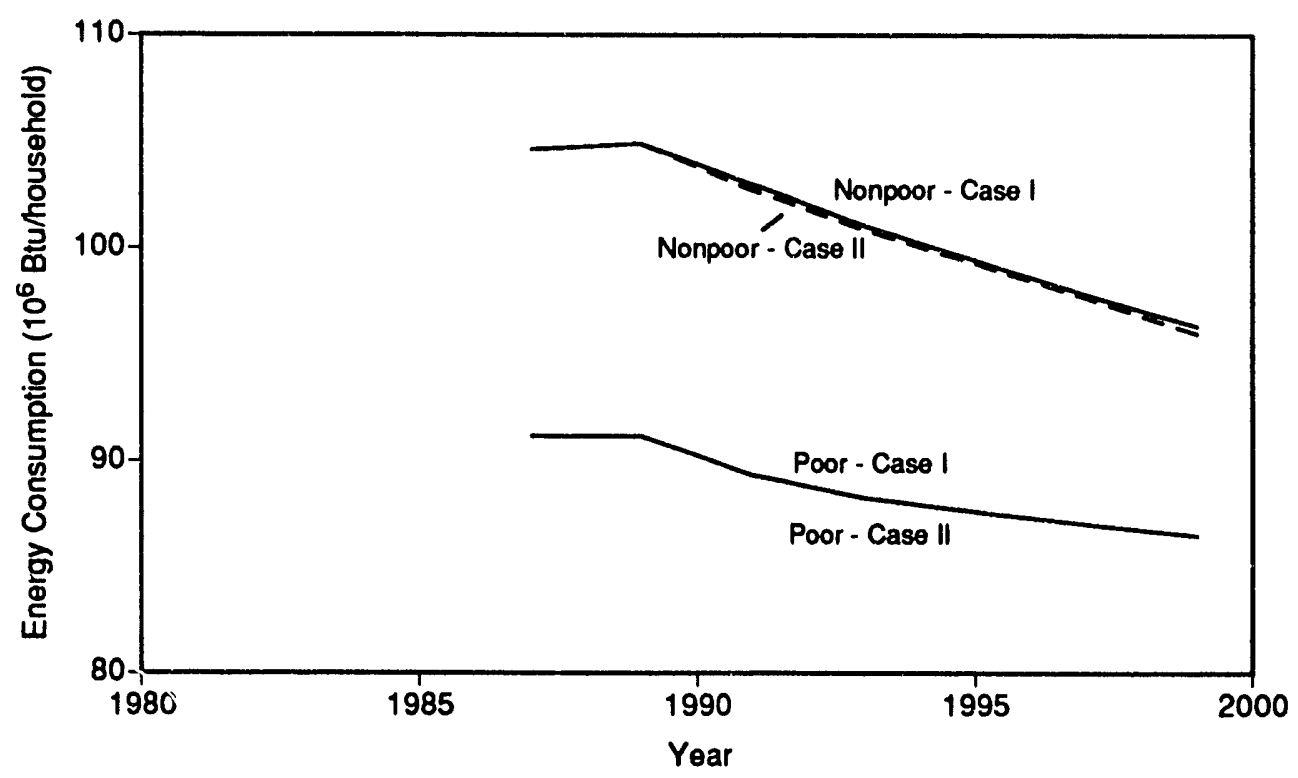

FIGURE 10 Energy Consumption of Poor and Nonpoor Households under Alternative Cases

\subsection{Total Energy Expenditures}

Table 4 provides estimated 1989 household energy expenditures for majority, black, Hispanic, poor, and nonpoor groups. Among these groups, total energy expenditure was highest for nonpoor households $(\$ 1,188 / \mathrm{yr})$ and almost as high for black households $(\$ 1,184 / \mathrm{yr})$. The expenditures were the lowest for poor households $(\$ 988 / \mathrm{yr})$.

Given the relative insensitivity of consumption with respect to rising energy prices, energy expenditures increase rather dramatically for each population group. Figures 11-15 show the projected household electricity and total energy expenditures for majority, black, Hispanic, poor, and nonpoor groups under the two cases. The greatest rise in expenditures for poor households occurs between 1989 and 1999 (a 64\% increase under Case I and a 73\% increase under Case II), which is in contrast to a $60 \%$ increase in the CPI under Case I and a $61 \%$ increase in the CPI under Case II.

\subsection{Energy Expenditure as Share of Income}

Table 5 lists the energy expenditures as shares of income for each of the groups for Case I and Case II. Figure 3 shows that under Case I, household income is forecast to increase at a higher rate than (1) electricity prices between 1989 and 1999 and (2) nonelectricity energy prices between 1989 and 1993. Because of the high rate of increase in household income, the percent of 
TABLE 4 Total Energy Expenditures

\begin{tabular}{|c|c|c|c|c|c|}
\hline \multirow[b]{3}{*}{ Group } & \multirow[t]{2}{*}{ Tota } & Energy & $\begin{array}{l}\text { xpenditure } \\
\text { by Case }\end{array}$ & \multicolumn{2}{|c|}{ (\$/household), } \\
\hline & & \multicolumn{2}{|l|}{ Case ! } & \multicolumn{2}{|c|}{ Case II } \\
\hline & 1989 & 1993 & 1999 & 1993 & 1999 \\
\hline Majority & 1,154 & 1,298 & 1,780 & 1,359 & 1,864 \\
\hline Black & 1,184 & 1,338 & 1,891 & 1,414 & 1,997 \\
\hline Hispanic & 1,042 & 1,186 & 1,695 & 1,252 & 1,784 \\
\hline Poor & 988 & 1,122 & 1,614 & 1,188 & 1,705 \\
\hline Nonpoor & 1,188 & 1,341 & 1,850 & 1,403 & 1,932 \\
\hline
\end{tabular}

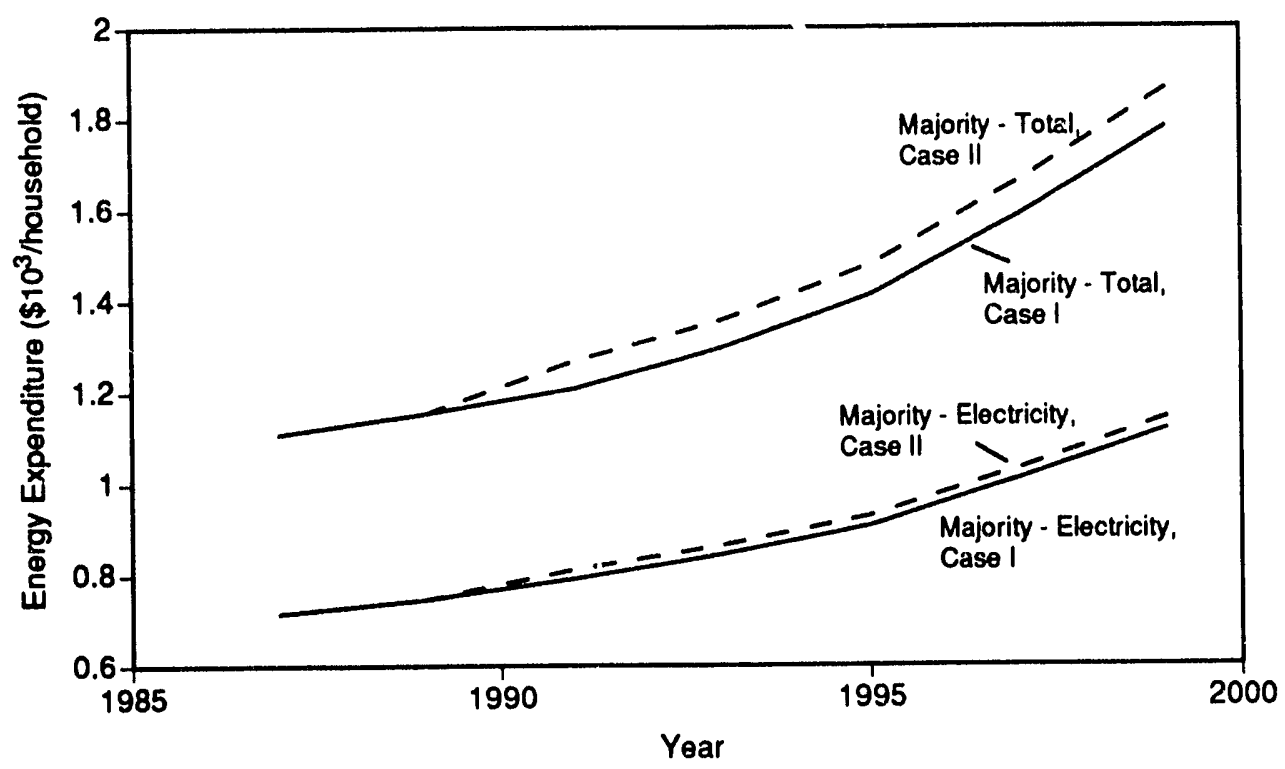

FIGURE 11 Energy Expenditures of Majority Households under Alternative Cases 


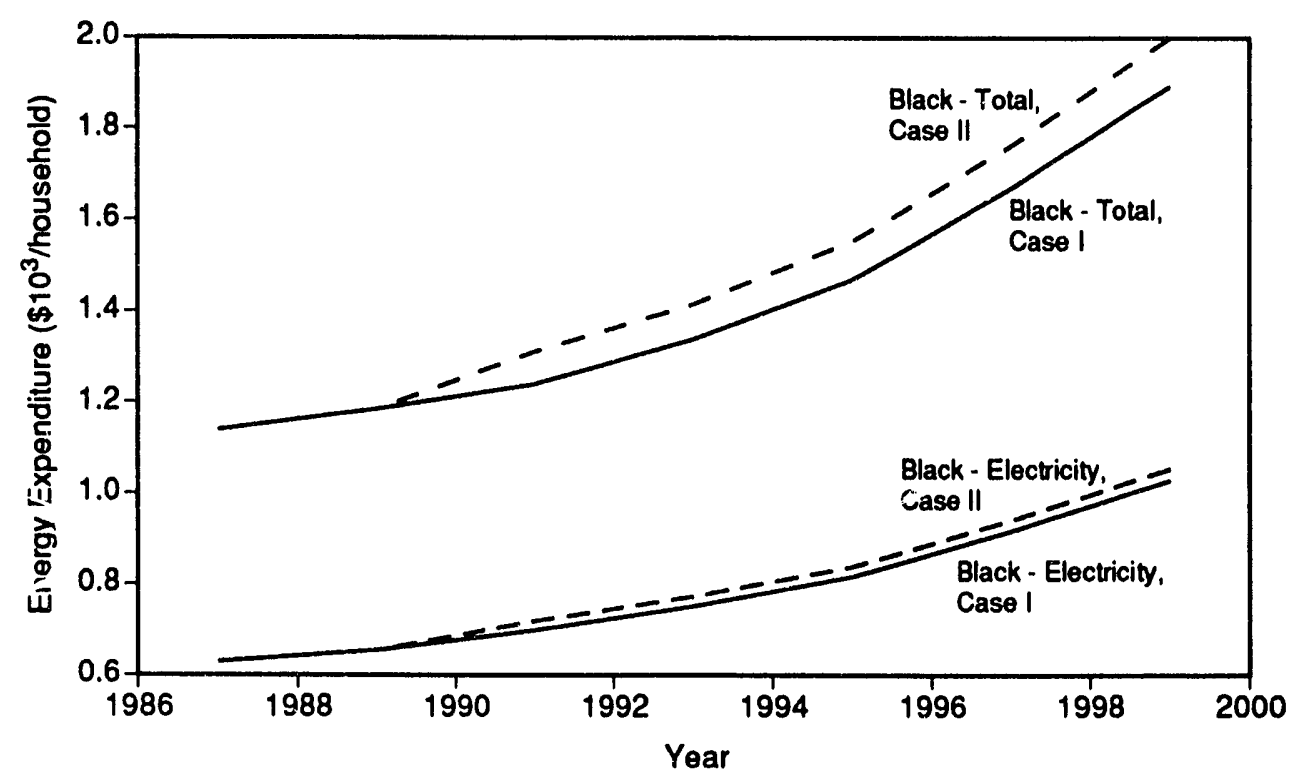

FIGURE 12 Energy Expenditures of Black Households under Alternative Cases

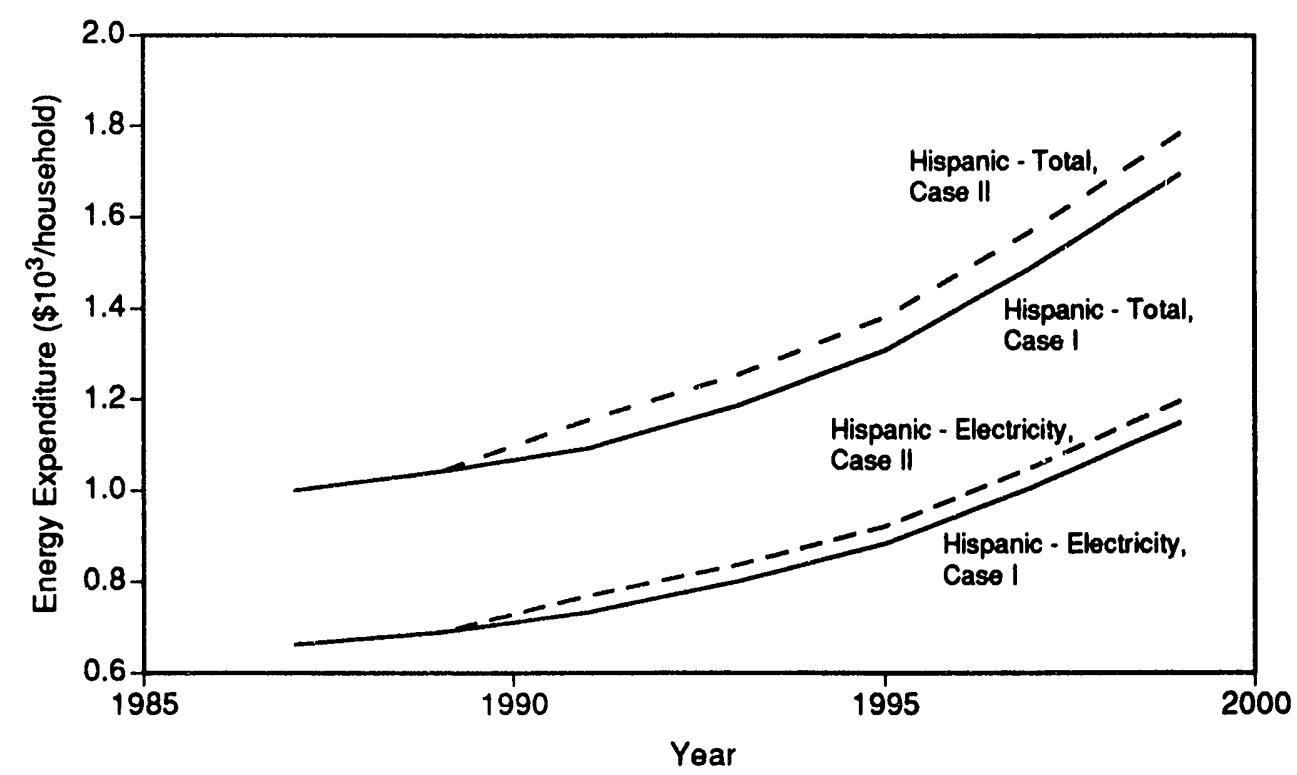

FIGURE 13 Energy Expenditures of Hispanic Households under Alternative Cases 


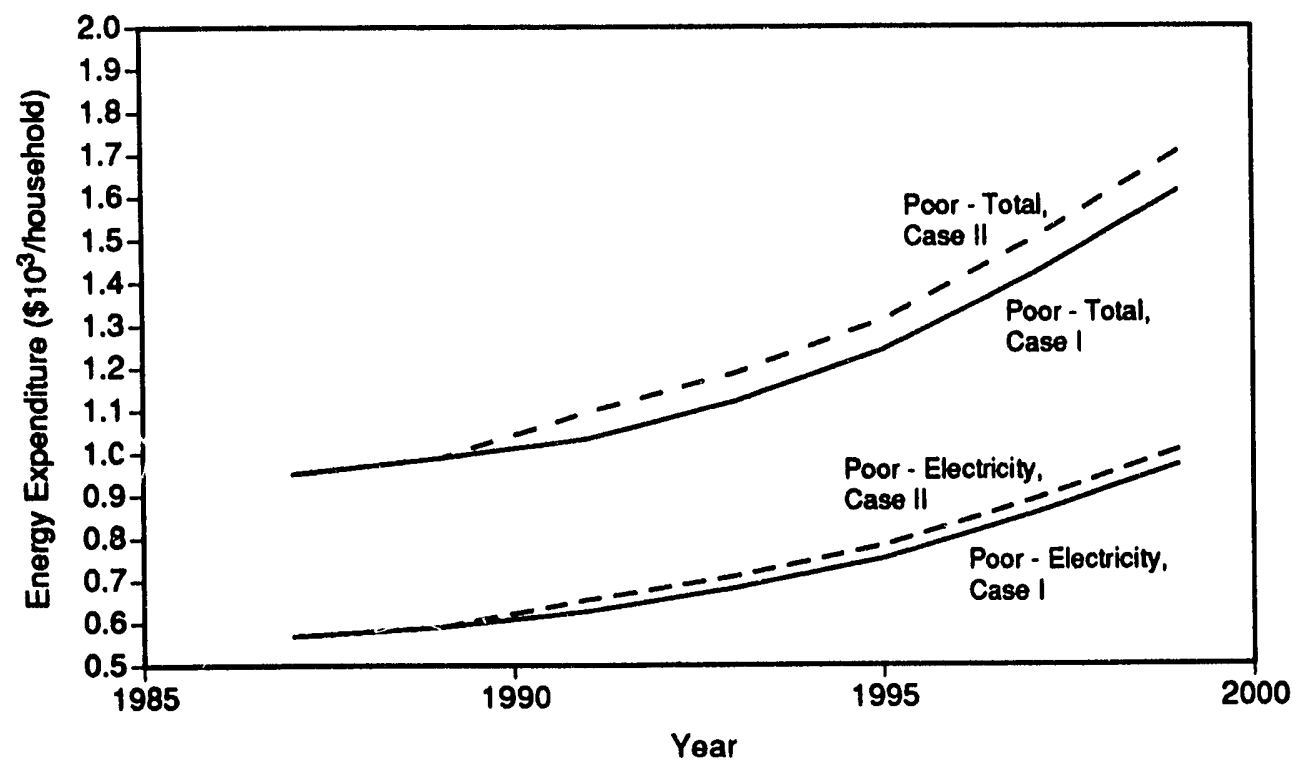

FIGURE 14 Energy Expenditures of Poor Households under Alternative Cases

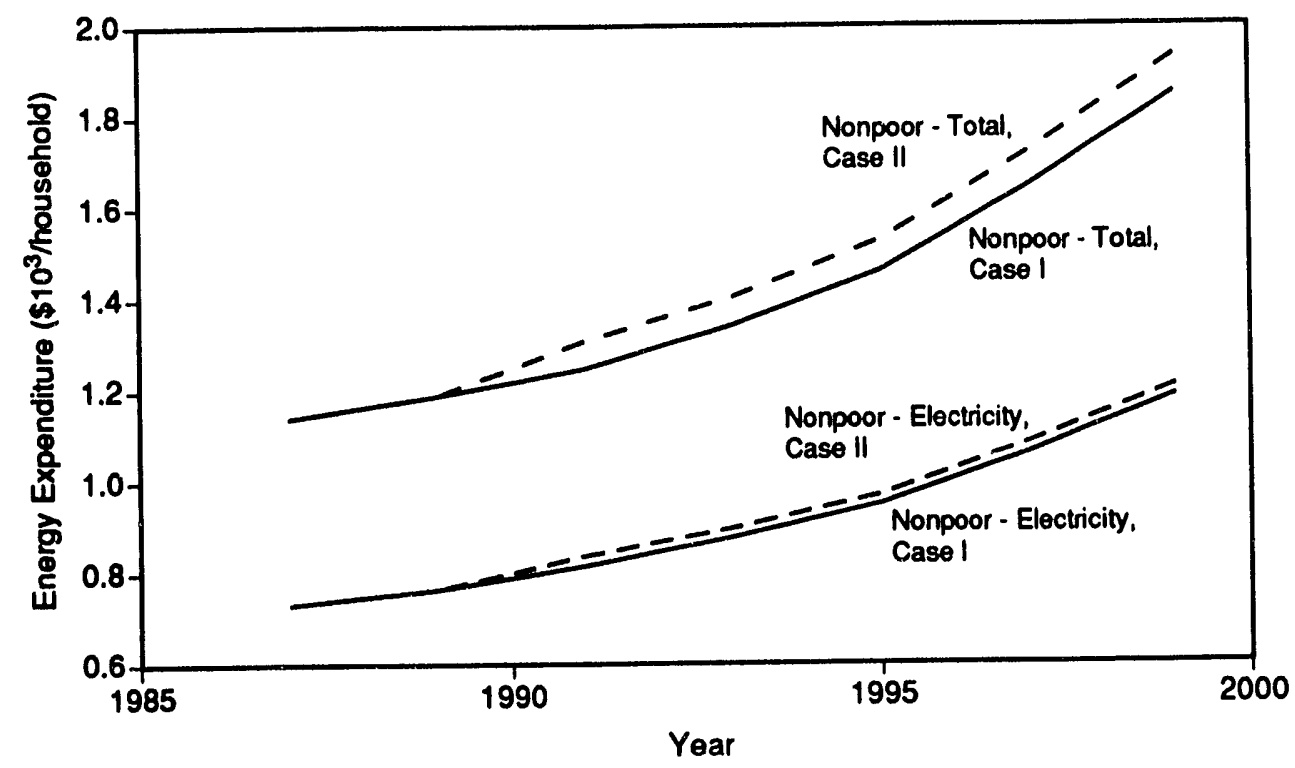

FIGURE 15 Energy Expenditures of Nonpoor Households under Alternative Cases 
TABLE 5 Total Energy Expenditure as Share of Income

\begin{tabular}{|c|c|c|c|c|c|}
\hline \multirow[b]{3}{*}{ Group } & \multicolumn{5}{|c|}{$\begin{array}{c}\text { Total Energy Expenditure as Share of Income } \\
(\%) \text {, by Case }\end{array}$} \\
\hline & \multicolumn{3}{|c|}{ Case 1} & \multicolumn{2}{|c|}{ Case II } \\
\hline & 1989 & 1993 & 1999 & 1993 & 1999 \\
\hline Majority & 3.21 & 2.94 & 2.88 & 3.14 & 3.07 \\
\hline Black & 5.23 & 4.82 & 4.85 & 5.19 & 5.23 \\
\hline Hispanic & 3.41 & 3.17 & 3.22 & 3.41 & 3.46 \\
\hline Poor & 11.97 & 11.08 & 11.36 & 11.96 & 12.24 \\
\hline Nonpoor & 2.96 & 2.73 & 2.68 & 2.91 & 2.86 \\
\hline
\end{tabular}

income spent on energy declines continuously from 1989 to 1995 for all groups (Figures 16 and 17). After 1995, energy expenditure as share of income begins to increase slightly, because the rate at which nonelectricity prices increase is faster than the rate at which household income increases. By 1999, energy expenditure as share of income is forecast to be below its 1989 level by $0.33 \%$ for majority households, $0.38 \%$ for black households, $0.19 \%$ for Hispanic households, $0.61 \%$ for poor households, and $0.28 \%$ for nonpoor households.

Under Case II, following the higher prices for crude oil in 1991 that result from the Persian Gulf conflict, energy expenditure as share of income for each of the household groups increases in 1991. As the oil market declines by mid-1992, the expenditure as share of income for each of the household groups decreases in 1993 and 1995 (Figures 16 and 17). Crude oil prices decline to $\$ 20 / \mathrm{bbl}$ by mid-1992 as markets decline, but prices remain slightly higher than the basecase proiections during the $1993-2000$ period. Like the base case, the energy expenditure as share of income falls in 1993 and 1995, but rises thereafter. For all groups, however, the energy expenditure as share of income under Case II remains higher than the energy expenditure as share of income under Case I. For the Hispanic and poor groups, the levels of energy expenditure as share of income increase and cross their 1989 levels in 1997 and continue to rise thereafter. By 1999, the shares are higher than their 1989 levels by $0.05 \%$ for Hispanic households and $0.27 \%$ for poor households. For black households, the 1999 level of energy expenditure as share of income matches its 1989 level. The difference, however, between the 1999 shares and the 1989 shares for majority and nonpoor groups is narrow. Specifically, the 1999 energy expenditure as share of income is forecast to be below its 1989 level by only $0.14 \%$ for majority households and by only $0.10 \%$ for nonpoor households. 


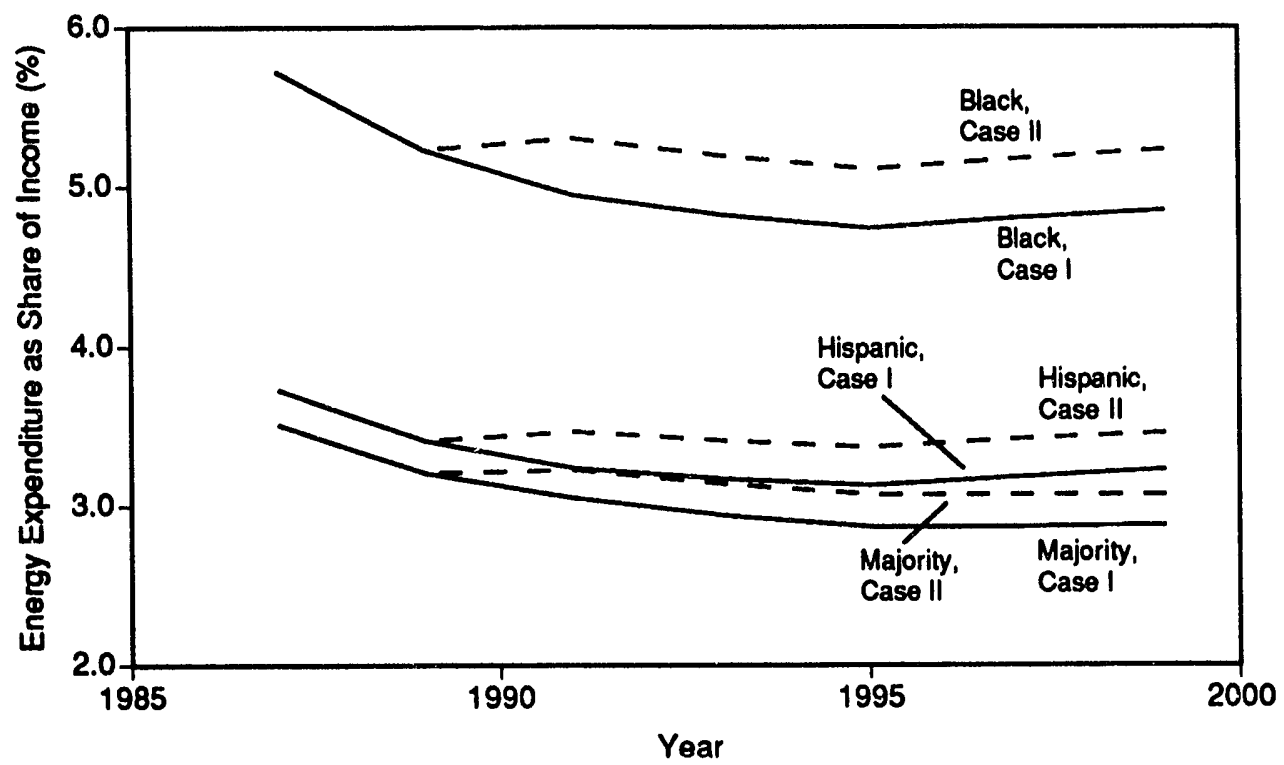

FIGURE 16 Energy Expenditure as Share of Income for Majority, Black, and Hispanic Households under Alternative Cases

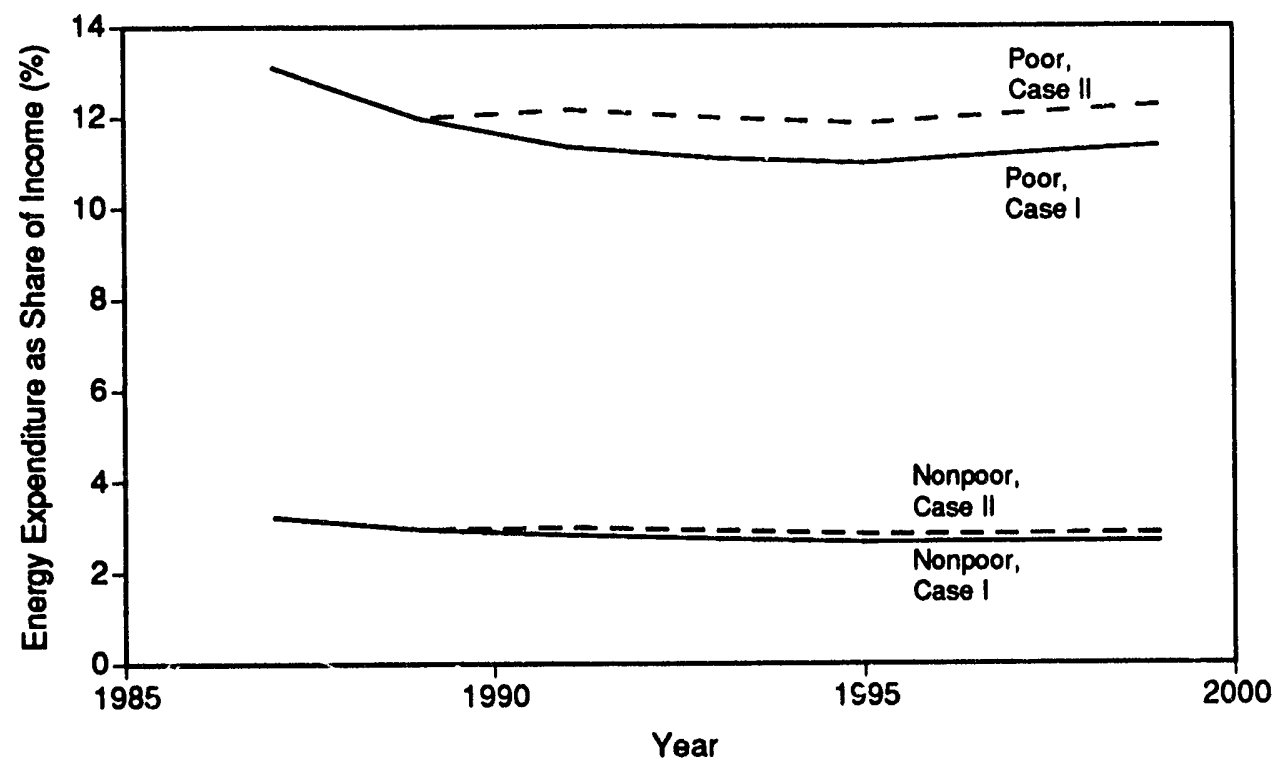

FIGURE 17 Energy Expenditure as Share of Income for Poor and Nonpoor Households under Alternative Cases 


\section{Conclusions}

Several major conclusions can be drawn from the analysis. Among all household groups in 1989, total energy consumption was highest for black households $\left(112 \times 10^{6} \mathrm{Btu} /\right.$ household $)$ and lowest for Hispanic households $\left(88 \times 10^{6} \mathrm{Btu} /\right.$ household). Total energy expenditure was highest for nonpuor households ( $\$ 1,188 /$ household) and black households $(\$ 1,184 /$ household), while total energy expenditure was lowest for poor households $(\$ 988 /$ household). Although energy expenditure was highest for nonpoor households, energy expenditure as share of income was highest for poor householdi (12.0\%) and lowest for nonpoor households (3.0\%). Under both Case I and Case II, total energy consumption peaks in 1989 for all households. This peak occurs mostly because the analysis presented in this report assumes that over the 1989-99 period, the energy-demand curves for each of the five population groups fall by $10 \%$, while the electricitydemand curves rise by $10 \%$ to reflect an increase in the proportions of households located in the South and West and a higher incidence of electricity use in new homes. Additionally, because of the resulting higher energy prices, the Persian Gulf Crisis (Case II) caused a slight reduction in household energy consurnption for all population groups throughout the 1989-99 period. Under both Case I and Case II, the decline in consumption during the 1989-99 period is lowest for poor households.

Household energy expenditures over the 1989-99 period increased for all population groups under both cases, but the increases were disproportionately higher for poor, Hispanic, and black households. The discrepancy in household energy expenditures is mostly attributed to the differences in price elasticities; poor and minority energy expenditures are more sensitive to rising nonelectricity energy prices. Also, the change in household energy expenditures is a result of the long-term effect of the fuel price shock under Case II. Although crude oil prices declined after the end of the Gulf Crisis, energy prices still remain at slightly higher levels than those under Case I. In addition, many consumer energy-conservation measures taken during the crisis are irreversible and remain in effect over the long run. Energy expenditures rise the most for poor households between 1989 and 1999 (64\% under Case I and 73\% under Case II), a rise that is in contrast to a $60 \%$ increase in the consumer price index under Case I and a $61 \%$ increase in the CPI under Case II.

Under Case I, the 1999 energy expenditures as shares of income are forecast to be below their 1989 levels by only $0.33 \%$ for majority households, $0.38 \%$ for black households, $0.19 \%$ for Hispanic households, $0.61 \%$ for poor households, and $0.28 \%$ for nonpoor households. Under Case II, however, energy expenditure as share of income is more variable than under Case I. Specifically, the 1999 energy expenditures as shares of income are forecast to be below their 1989 levels by $0.14 \%$ for majority households and by $0.10 \%$ for nonpoor households. In contrast, the 1999 energy expenditures as shares of income are expected to be unchanged for black households and above their 1989 levels by $0.05 \%$ for Hispanic households and by $0.27 \%$ for poor households. 
As they would for any model and its application, certain limitations apply. First, the scope of the racial/ethnic minorities in the model is limited to black households and Hispanic households. Because observations in DOE's RECS data are limited to these minorities, the model could not be extended to include other minority groups, such as American Indians and Asian-Americans. Second, the parameterj of the MEAM equations are estimated on the basis of the RECS database, which is now available only every three years. Because the model captures movements over a two-year period, it is more suitable for intermediate-term and long-run asialyses than for short-run analyses. Third, the energy demand projections are based on the assumption that household income for each group increases at the same rate - variations in the actual rates will affect both expenditure share and, to a lesser extent, energy consumption estimates. These analytical limitations indicate areas that warrant further research. 


\section{References}

Amemiya, T., 1985, Advanced Econometrics, Harvard University, Cambridge, Mass.

DRI, 1989, Energy Review: Winter 1988-89, Data Resources, Inc., Lexington, Mass.

DRI, 1990a, Energy Review: Spring 1990, Data Resources, Inc., Lexington, Mass.

DRI, 1990b, Revisw of the US. Economy, Septemher 1990, Data Resources, Inc., Lexington, Mass.

Geary, R.C., 1950-51, A Note on "A Constant Utility Index of the Cost of Living," Review of Economic Studies, 15:65-66.

Klein, L.R., and H. Rubin, 1947-48, A Constant-Utility Index of the Cost of Living, Review of Economic Studies, 15:84-87.

Muellbaver, J., 1981, The Cost of Living and Taste and Quality Change, Journal of Economic Theory, 10:269-283.

Phlips, L, 1972, A Dynamic Version of the Linear Expendinure Model, Review of Economics and Statistics, 54:450-58.

Phlips, L., 1983, Applied Consumption Analysis, North-Holland Publishing Company, Amsterdam.

Pollak, R.A., and T J. Wales, 1981, Demographic Variables in Demand Analysis, Econometrica, 49:1533-1551.

Samuelson, P.A., 1947-48, Some Implications of "Linearity," Review of Economic Studies, 15:88-90.

SAS Institute, 1984, SAS/ETS User's Guide Version 5 Edition, Cary, North Carolina.

Stone, R., 1954, Linear Expenditure Systems and Demand Analysis: An Application to the Pattern of British Demand, Economic Joumal, 64:511-27.

DOE, 1982, Residential Energy Conswomption Survey 1980-1981, U.S. Department of Energy, Energy Information Administration, public-use data tape.

DOE, 1985, Residentiai Energy Consumption Survey 1982-1983, U.S. Department of Energy, Energy Information Adninistration, poblic-use data tape. 
DOE, 1987, Residential Energy Consumption Survey 1984-1985, U.S. Department of Energy, Energy Information Administration, public-use data tape.

DOE, 1989, Residential Energy Consumption Survey 1987, U.S. Departinent of Energy, Energy Information Administration, public-use data tape. 


\section{References}

Amemiya, T., 1985, Advanced Econometrics, Harvard University, Cambridge, Mass.

DRI, 1989, Energy Review: Winter 1988-89, Data Resources, Inc., Lexington, Mass.

DRI, 1990a, Energy Review: Spring 1990, Data Resources, Inc., Lexington, Mass.

DRI, 1990b, Review of the U.S. Economy, September 1990, Data Resources, Inc., Lexington, Mass.

Geary, R.C., 1950-51, A Note on "A Constant Utility Index of the Cost of Living," Review of Economic Studies, 15:65-66.

Klein, L.R., and H. Rubin, 1947-48, A Constant-Utility Index of the Cost of Living, Review of Economic Studies, 15:84-87.

Muellbauer, J., 1981, The Cost of Living and Taste and Quality Change, Journal of Economic Theory, 10:269-283.

Phlips, L., 1972, A Dynamic Version of the Linear Expenditure Model, Review of Economics and Statistics, 54:450-58.

Phlips, L., 1983, Applied Consumption Analysis, North-Holland Publishing Company, Amsterdam.

Pollak, R.A., and T.J. Wales, 1981, Demographic Variables in Demand Analysis, Econometrica, 49:1533-1551.

Samuelson, P.A., 1947-48, Some Implications of "Linearity," Review of Economic Studies, 15:88-90.

SAS Institute, 1984, SAS/ETS User's Guide Version 5 Edition, Cary, North Carolina.

Stone, R., 1954, Linear Expenditure Systems and Demand Analysis: An Application to the Pattern of British Demand, Economic Journal, 64:511-27.

DOE, 1982, Residential Energy Consumption Survey 1980-1981, U.S. Department of Energy, Energy Information Administration, public-use data tape.

DOE, 1985, Residential Energy Consumption Survey 1982-1983, U.S. Department of Energy, Energy Information Administration, public-use data tape. 
DOE, 1987, Residential Energy Consumption Survey 1984-1985, U.S. Department of Energy, Energy Information Administration, public-use data tape.

DOE, 1989, Residential Energy Consumption Survey 1987, U.S. Department of Energy, Energy Information Administration, public-use data tape. 
